\title{
SOBRE A CAPA
}

\section{MENINA MORENA E ÁGIL}

Pablo Neruda

Menina morena e ágil, o sol que faz as frutas, o que madura os trigos, o que retorce as algas, faz teu corpo alegre, teus luminosos olhos e tua boca que tem o sorriso da água.

Um sol negro e ansioso te enrola nas ervas da negra melena, quando estiras os braços. Tu brincas com o sol como com um arroio e ele te deixa nos olhos dois escuros remansos.

menina morena e ágil, nada a ti me aproxima. Tudo de ti me afasta, como do meio-dia. És a delirante juventude da abelha, a embriaguez da onda, a força da espiga.

Meu coração sombrio te procura, sem embargo, e amo teu corpo alegre, tua voz solta e delgada. Borboleta morena doce e definitiva como o trigal e o sol, a papoula e a água.

(Vinte Poemas de Amor e uma Canção Desesperada) 
